Sven Egil Omdal

Journalist

Foto: Ingeborg Eliassen

\title{
«La dem falle»
}

\section{Hva skal en stakkars pleier gjøre hvis moralen sier: Grip inn!, mens arbeidsinstruksen sier: La være!}

I november i fjor ble Betina Byrk sykmeldt. Den 30 år gamle sosial- og helsepleieren jobber i hjemmesykepleien i Odense kommune og var hjemme hos en eldre pasient, en stor og tung mann. På vei ut på badet med rullatoren sviktet beina under ham.

Da pasienten ropte: «Nå faller jeg,» kastet Betina Byrk ut en arm og fikk holdt ham oppreist.

Det skulle hun ikke gjort. Odense har, som flere andre danske kommuner, en instruks som oppfordrer medarbeiderne i helsetjenesten til å la de gamle falle. Århus har en slik regel. Det samme har Rosenkilde. I København er den skrevet inn i personalhåndboken. Hensikten er å unngå det som skjedde med Betina Byrk. Rykket fra den fallende mannen påførte henne en begynnende skiveprolaps og halvannen måneds sykmelding. Dessuten påførte fallet Danmark en debatt om forholdet mellom plikt og moral. Edith Mark, postdoktor i klinisk sykepleie ved Aalborg Universitetshospital og tidligere medlem av dansk helsevesens etiske råd, sier til Kristeligt Dagblad at «det er laveste fellesnevner, hvis vi begynner å avgrense oss fra å hjelpe et annet menneske fordi vi selv kan bli skadet».

Min egen umiddelbare reaksjon var den samme. Hvem kan formulere en instruks som påbyr helsepersonell å forholde seg rolig hvis den de skal hjelpe, plutselig tipper over ende, med de følger det kan få?

Jeg har nylig opplevd hvilke følger det kan være snakk om. De siste dagene har jeg tilbrakt ved dødsleiet til en person som står meg nær. Hun falt på badet og brakk lårhalsen. I de slitsomme døgnene har jeg sett henne omsluttet av en grenseløs profesjonell omsorg, først på sykehuset, senere på sykehjemmet. Pleierne snur henne, steller henne, masserer føttene hennes og fukter leppene hennes. Jeg kan ikke tenke meg at noen av dem ville latt henne falle om de kunne forhindret det. Men har jeg rett til å kritisere dem, hvis de så gjorde?

Jeg kjenner ikke de norske statistikkene, så jeg holder meg til de danske. Av de 375000 danskene som er eldre enn 75 år, faller nesten halvparten i løpet av et år. Ofte er det ingen i nærheten til å ta imot dem, så de treffer gulvet med den tyngden de har. Har vi, som ikke løfter noe tyngre enn en penn, rett til å kreve at pleieren risikerer ryggen for å hindre at hodet treffer gulvet eller kanten på en kommode?

«Det lyder temmelig barskt når vi sier «ikke ta dem»,» sier Lars Erik Bengtsson, arbeidsmiljøkoordinator i Odense kommune til nettstedet etik. $d k$. «Men», legger han til, «forklaringen er at det er usannsynlig mange medarbeidere i hjemmepleien som er blitt ødelagt og uføretrygdet på grunn av borgere som har veltet». I Odense kommune ble det i fjor registrert 36 ryggskader med sykefravær, en vesentlig del av disse skyldtes «grep av borgere», som Bengtsson uttrykker det.

Jeg liker denne bruken av borgerbegrepet. Velferdsstatens idé er jo at noen skal ta imot når borgerne snubler og faller, enten det er i fysisk eller i overført betydning. Men så kom noen til å regne på hva slikt koster. Kommunen er ikke bare leverandør av omsorgstjenester, den er også arbeidsgiver med ansvar for de ansattes helse, og for kostnadsnivået. Kommunenes byråkrater har lagt inn parameterne i regnearkene, kalkulert forventet sykefravær, forsikringspremier og vikarkostnader og så trukket konklusjonen: La de gamle falle.

«Statistisk sett fører et lårbensbrudd ikke til en alvorlig lidelse, men for mennesker på 80 eller 90 år kan det være at man ikke kommer seg igjen (...) Men skal man være kynisk, kan man si at det er færre år igjen å leve enn hvis du er 20 og får ødelagt ryggen. Jeg vil forsvare at jeg mener dette, men det høres ikke bra ut, og ser ikke godt ut på trykk,» sier Bengtsson.

Bengtsson har god selvinnsikt. Det ser virkelig ikke bra ut. Må det virkelig lages en slik instruks? Kan vi ikke overlate denne avgjørelsen til den enkelte pleiers vurdering i stedet for å gjøre ulydige medarbeidere av dem som våger egen helse for å hindre andres lidelse?

Betina Byrk er tilbake i arbeid. Hun sier til etik.dk at selv om det gjorde avsindig vondt sist, vil hun ikke klare å si til den neste gamle som faller: «Det er beklagelig, men jeg har ikke lov til å ta deg.»

Det siste hun trenger er et skarpt brev fra HR-avdelingen.

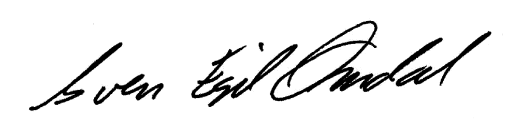

